\title{
THE GREEN MAN: WHAT READING AL-KHIDR AS TRICKSTER EVINCES ABOUT THE CANON
}

\author{
Jibril Latif \\ Gulf University for Science \& Technology, West Mishref-Kuwait \\ Latif.J@gust.edu.kw \\ https://orcid.org/0000-0002-1710-2586
}

\begin{abstract}
The Green Man is a deictic trans-historical figure and motif shared by both interconnected canons and folklores, as well as those seemingly disparate. Revered in varying capacities in mythology, literature, and architecture, the figure's analogs and accretions have manifold associations to religiously significant personalities like St. George, Elijah, Gilgamesh, Buddha, Christ, and Melchizedek. Often bridging the sacred and profane, the figure's literary function is unusually polyvalent and associative readings flexibly range from prophetic guide and reconciler of paradoxes, to boundary-crossing and subverting trickster. However, the trickster figure archetypally imparts moral lessons by upsetting conventions and norms; he can teach his lessons through terror, but he can also beguile. If this is the case only because his telos redounds to a pantheon of polytheism, how do these features obtain when bound by monotheistic-based canons? The enigmatic character in the Qur'ān, dubbed al-Khidir and revered in canonical contexts, similarly has a didactic trickster-like encounter with Moses, whom he guides on a journey of paradoxes and

Volume 11 Number 1 Winter / Spring 2020

p-ISSN: 1309-1786 / e-ISSN: 1309-1719

DOI: $10.12730 / 13091719.2020 .111 .199$

Copyright (C) Bursa İlahiyat Foundation
\end{abstract}

Ilahiyat Studies

Received: December 12, 2019

Accepted: April 17, 2020

Published: June 30, 2020

To cite this article: Latif, Jibril. "The Green Man: What Reading Khiḍr as Trickster Evinces about the Canon." Ilabiyat Studies 11, no. 1 (2020): 9-46. https://doi.org/10.12730/13091719.2020.111.199 
reconciliations. As they manifest in other contexts, various permutations are only reconciled if a division is based on telos because the character's abundantly operative meaning is predicated on the realism of established canonical boundaries, which evinces why nominalist ontology struggles to cohere with various folkloric interpretations. Consequently, despite the recent pushback against canons, making such a compulsory distinction for a boundarycrossing character argues for affirming the continued relevance of such boundaries.

Key Words: Al-Khiḍdr, Green Man, trickster, Sufism, canon, folklore

\section{Introduction to the Green Man Motif}

Why do modern cultural appropriations like Yoda, the wise green leader of the Jedi, continue to resonate with audiences? ${ }^{1}$ Is there something archetypal or essential about such figures? Surely, the Green Man motif is found throughout the world as a syncretized figure that is bound by attributes oft-associated to fertility, the color green, water, mystical rebirth, spiritual guidance, and companionship. However, abounding Green Man artwork, literature, and lore all display equivalences among canonical and folkloric traditions. The legend of Elijah, for instance, associates a venerated biblical prophet of the wilderness to the unifying water springs of Bethany. ${ }^{2}$ Often, the Green Man becomes a militant hero, as is the case with St. George more so than others, but St. Elias (Elijah), St. Behnam, and St. Sergius do as well. The immortal figure has also been linked to the Wandering Jew legend that spread across Europe in the $13^{\text {th }}$ century, and there is ample Green Man architecture found across Europe and Asia linked to various fertility gods. A parallel also exists with Sir Gawain and the Green Knight, the Arthurian Middle

1 Despite George Lucas repudiating that Yoda is anything other than "a totally normal guy," the amalgamation of characteristics borrows from the motif. See George Lucas, "Yoda Is Supposed to be just a Normal Guy," https://www.clickhole.com/yoda-is-supposed-to-be-just-a-normal-guy1829478120, accessed October 11, 2019.

2 Mark Amaru Pinkham, Guardians of the Holy Grail: The Knights Templar, John the Baptist, and the Water of Life (Kempton, IL: Adventures Unlimited Press, 2004), 90. 
English chivalric romance poem. ${ }^{3}$ The essential question I would pose to prospective readers is: what binds these seemingly disparate characters and their multifarious attributes that admits them to be identified as one and the same in numerous cases? In exploring this question further, this paper traces Islam's connection to the motif as introduced in the Qur'ān's $18^{\text {th }}$ chapter (sürah) titled The Cave in positing that intriguing cross-canonical functions and manifestations are bound in a way insufficiently explored.

In the $19^{\text {th }}$ century, Orientalists began studying Syriac texts in search of what they deemed to be the Qur'ān's source material. E. A. Wallis Budge edited narrations about Alexander the Great in 1889, which was later dubbed the Alexander Legend (Neṣhānâ). Building upon the work of G. J. Reinink and others, Kevin van Bladel theorizes that different traces of the Akkadian Epic of Gilgamesh can be found in the story about Moses that takes place between verses ( $\bar{a} y \bar{a} t) 60-83$ and posits that regarding the Syriac and Qur'ānic texts "there can be no doubt whatsoever of the affiliation." "4ike Moses, Gilgamesh's travel destination is a mystical water source, and Gabriel Said Reynolds has more recently followed up these links with an examination of point-by-point parallels in a huge variety of extrabiblical texts extant during late antiquity. ${ }^{5}$ While these pursuits are significant, classical Qur’ān commentators like al-Suyūṭi (d. 911/1505) and al-Rāzì (d. 606/1210) preceded the impetus of this modern inquiry by acknowledging links between Elijah, Gilgamesh, Alexander, and the story of Dhū l-qarnayn (Q 18:83-102). While more research is needed into discerning the significance of such links, it is in the didactic episode sequentially preceding the Quraanic story linked to Alexander ( $Q$ 18:60-83) that an intriguing figure teaches

3 Husayn Wāciz Kāshifī Sabzawārī, The Royal Book of Spiritual Chivalry (Futūwat nāmah-yi sulțānì), trans. Jay R. Crook (Chicago: Great Books of the Islamic World, 2000), 1-3.

4 Kevin van Bladel, "The Alexander Legend in the Qur'ān 18:83-102," in The Qur'ān and its Historical Context, ed. Gabriel Said Reynolds (London \& New York: Routledge, 2008), 183.

5 Gabriel Said Reynolds, The Qur'ān and the Bible: Text and Commentary, Qur'ān trans. Ali Quli Qarai (New Haven \& London: Yale University Press, 2018). 
Moses about reconciling paradoxes using an alternative type of logic. ${ }^{6}$ Popularly dubbed al-Khidir, he is a character who initially seems to share many of the motif's characteristics. Whether the name al-Khidr is a title or an epithet is a point for debate. ${ }^{7}$ But in a hadith the Prophet Muhammad says, "He was named al-Khiḍr because he sat upon barren land and when he did, it became green with vegetation." In Arabic, al-Khiḍr, Verdant or Green One, implies a possessor of greening, renewing effects on places, people, spirits, and souls. Theorized by some as Alexander's vizier who fortuitously stumbled upon the fountain, (while Alexander in contrast did not), he is introduced in the Qur'ān simply as God's "servant."

(60) And when Moses said unto his servant, "I shall continue on till I reach the junction of the two seas, even if I journey for a long time." (61) Then when they reached the junction of the two, they forgot their fish, and it made its way to the sea, burrowing away. (62) Then when they had passed beyond he said to his servant, "Bring us our meal. We have certainly met with weariness on this journey of ours." (63) He said, "Didst thou see? When we took refuge at the rock, indeed I forgot the fish-and naught made me neglect to mention it, save Satan-and it made its way to the sea in a wondrous manner!" (64) He said, "That is what we were seeking!" So they turned back, retracing their steps. (65) There they found a servant from among Our servants whom We had granted a mercy from Us and whom We had taught knowledge from Our Presence. (66) Moses said unto him, "Shall I follow thee, that thou mightest teach me some of that which thou hast been taught of sound judgment?" (67) He said, "Truly thou wilt not be able to bear patiently with me. (68) And how canst thou

6 The word $\bar{a} y a h$ (pl. $\bar{a} y \bar{a} t$ ) linguistically means "a sign" to be pondered and is used herein to equate "verse."

7 Arent Jan Wensinck, "al-Khadir (al-Khiḍr)," in Encyclopaedia of Islam, third impression, ed. P. Bearman, Th. Bianquis, C. E. Bosworth, E. van Donzel, W. P. Heinrichs (Leiden: Brill, 1997), IV, 904-905.

8 The hadith (pl. ahāaith) collections are rigorously authenticated statements, actions, and approved norms attributed to the Prophet Muhammad that formulate a comprehensive understanding of his normative practice.

9 All Qur'ānic quotes utilize translations from Seyyed Hossein Nasr et al, eds., The Study Quran: A New Translation and Commentary (New York, NY: HarperOne, an Imprint of HarperCollins Publishers, 2017), 750. 
bear patiently that which thou dost not encompass in awareness? (69) He said, "Thou wilt find me patient, if God wills, and I shall not disobey these in any matter." (70) He said, "If thou wouldst follow me, then question me not about anything, till I make mention of it to thee." (71) So they went on till, when they had embarked upon a ship, he made a hole therein. He said, "Didst thou make a hole in it in order to drown its people? Thou hast done a monstrous thing!" (72) He said, "Did I not say unto thee that thou wouldst not be able to bear patiently with me?" (73) He said, "Take me not to task for having forgotten, nor make me suffer much hardship on account of what I have done." (74) So they went on till they met a young boy, and he slew him. He said, "Didst thou slay a pure soul who had slain no other soul? Thou hast certainly done a terrible thing!" (75) He said, "Did I not say unto thee that thou wouldst not be able to bear patiently with me?" (76) He said, "If I question thee concerning aught after this, then keep my company no more. Thou has attained sufficient excuse from me." (77) So they went on till they came upon the people of a town and sought food from them. But they refused to show them any hospitality. Then they found therein a wall that was about to fall down; so he set it up straight. He said, "Hadst thou willed, thou couldst have taken a wage for it." (78) He said, "This is the parting between thee and me. I shall inform thee of the meaning of that which thou couldst not bear patiently: (79) As for the ship, it belonged to indigent people who worked the sea. I desired to damage it, for just beyond them was a king who was seizing every ship by force. (80) And as for the young boy, his parents were believers and we feared that he would make them suffer much through rebellion and disbelief. (81) So we desired that their Lord give them in exchange one who is better than him in purity, and nearer to mercy. (82) And as for the wall, it belonged to two orphan boys in the city, and beneath it was a treasure belonging to them. Their father was righteous, and thy Lord desired that they should reach their maturity and extract their treasure, as a mercy from thy Lord. And I did not do this upon my own command. This is the meaning of that which thou couldst not bear patiently."

In this episode al-Khiḍr is simultaneously the teacher's sage and perceivably an antinomian; while seemingly breaking the sacred law,

10 Nasr et al., The Study Quran, 743. 
his lessons teach about contemplation and reconciling opposites. The Prophet Muhammad recommended the recitation of The Cave every Friday and it is thus oft read. However, considering that a singular motif plausibly links multiple doctrines, al-Khị̣r is highly undertheorized. His characterization as enigmatic and mysterious may factor in this neglect, but if posited links hold up to more discerning scrutiny it is plausible that he foundationally connects several of the world's great traditions in ways hitherto unexhausted. One underexplored association is to that of Melchizedek, King of Salem, a biblical contemporary of Abraham whom Abraham praises and blesses in The Book of Genesis (14: 18-20). Another link is to one of the readings of the Buddha. The Three Baskets (Tripitaka) comprises the essential canon of Buddhists entailing works directly and indirectly ascribed in authorship to the Buddha, and through analysis of this early narrative literature Sarah McClintock envisages Buddha as a paradox, an unconditioned yet compassionate trickster who uses deceptions in helping people experience their limitations along the path to transformation. ${ }^{11}$ In the polymath Muhammad alShahrastānī's (d. 548/1153) early systematic study of religion, Religions and Sects, Buddha is linked to al-Khidir at the end of a passage on Buddhists, which ends abruptly and offers no further elucidation. ${ }^{12}$ Bruce Lawrence questions whether al-Shahrastānī's comparison is original or if it stems from an irrecoverable earlier source because while the link is tantalizingly suggestive in its "implicitly attesting to the high spiritual quality of Buddhism" Lawrence argues that the case rests too squarely on a Muslim reading of sources. ${ }^{13}$ In contrast, Hamza Yusuf's essay "Buddha in the Qur'ān?" probes the same association, noting that numerous classical exegetes corroborate al-Shahrastānī's claim. He opines that the Prophet Muhammad's explicit statements about al-Khị̂r could easily

11 Sara L. McClintock, "Compassionate Trickster: The Buddha as a Literary Character in the Narratives of Early Indian Buddhism," Journal of the American Academy of Religion 79, no. 1 (2011), 90-91, https://doi.org/10.1093/jaarel/lfq061.

12 "... wa-laysa yushbihu l-budd 'alá mā waṣafūbu, in șaddaqū fa-dhālika illā bi-lKhiḍr alladhī yuthbitubū abl al-Islām." Abū l-Fatḥ Tāj al-Dīn Muhammad ibn 'Abd al-Karīm al-Shahrastānī, al-Milal wa-l-niḥal, ed. Amīr 'Alī Mahnā and 'Alī Hasan Fā̄ūr, $3^{\text {rd }}$ ed. (Beirut: Dār al-Ma'rifah, 1993), II, 604.

13 Bruce B. Lawrence, Shabrastani on the Indian Religions (The Hague: Mouton, 1976), 114, https://doi.org/10.1515/9783110800999. 
be ascribed to Gautama Buddha, and that reading them in such light bolsters the link because they substantiate al-Khiḍr's symbolic connection to the color green, the large white lotus flower, and background, as one badith states "He was the son of a king who desired that his son inherit his throne, but he refused and fled to a secluded island place where they could not find him." ${ }^{14}$ However, in another hadith, al-Khiḍr is named a noble of the tribe of Israel. Therefore, in attempting to reconcile the perceived chronological, geographical, and conceptual discrepancies between linking the characters, Yusuf notes:

... [a] widespread belief among Muslims is that al-Khadir does not die until the end of time. Hence, al-Shahrastānī would not have been troubled by this historical discrepancy - between the recorded historical dates of Moses and the Buddha is a distance of approximately 700 years - since he would have most likely held the belief that al-Khadir was a transhistorical character. It is also possible to interpret the figure of al-Khadir as a supra-historical archetype, or a particular mode of spiritual guidance -antinomian and enigmatic, radically transcending human modes of comprehension, and even "normal" modes of prophetic guidance. Thus, rather than simply seeking to establish a historical connection or identification between al-Khadir and the Buddha, one might also see the Buddha as one manifestation of the spiritual archetype articulated by the Qur'anic figure al-Khadir. ${ }^{15}$

A spiritual archetype is something quite enigmatic and difficult to delineate, which is how this link seems to bind characters ranging from sage to antinomian. Another way the phenomenon has been categorized is as part of mundus imaginalis, Henry Corbin's term for describing the imaginal realm that pertains to the world of images in the cosmology of Islamic mysticism; thus, al-Khị̂r can simultaneously be perceived as a conduit for communicating the religious, the cultural, and the inner experience of divine presence. ${ }^{16}$

14 Shaykh Hamza Yusuf, "Buddha in the Qur’ān?," in Common Ground Between Islam \& Buddhism by Reza Shah Kazemi (Louisville, KY: Fons Vitae, 2010), 120121.

15 Yusuf, "Buddha in the Qur’ān?," 119-120.

16 Irfan A. Omar, "Reflecting Divine Light: al-Khidr as an Embodiment of God's Mercy (rahma)," in Gotteserlebnis und Gotteslehre: Christliche und islamische 
Although the bulk of canonical commentary on al-Khidr confers meaning onto him independent of characterizations of the Green Man in other traditions, Muslim exegetes historically acknowledge a wide range of associations, including his connection to Elijah, Gilgamesh, and Alexander. However, beyond the Islamic canon where his role as God's servant does not maintain its primacy, the character's functions expand and incline towards a different telos. Intimating the reservations of many devotional Islamic scholars, Irfan Omar opines for a reading of the figure from within a monotheistic cosmology as God's mercy in concert with the "light" of spiritual illumination, and he argues against pliant archetypal analysis, "If, taking the standpoint of analytical psychology, we speak of Khidr as an archetype, he will seem to lose his reality and become a figment of the imagination, if not of the intellect." ${ }^{17}$ This is a general argument about such appropriation although this reference is made specifically in regards to Carl Jung's identification of al-Khidir as one of the four archetypes that he used to teach his clients about reconciling paradox. ${ }^{18}$ In literary analysis, al-Khidir seems able to more or less maintain his thrust as a religious hero. John Renard notes, for instance, that he can maintain reverence while simultaneously having "the ability of the picaresque trickster hero to get away with a variety of deeds that would land anyone else in serious trouble." ${ }^{19}$ It is to these overlaps in claims that the following sections address. Yusuf, Omar, and Renard all make valid assertions; al-Khiḍr is mutually an archetypal, canonical, and literary figure because the Qur’ān is, not primarily, but among other things, a literary text. But can al-Khiḍr's function in the Qur'ān as a reconciler of paradox fit the characteristics of a quintessential trickster? And if so, what are the implications? As follows, the remainder of this study explores al-Khidr as the trickster, and while it cannot exhaust his rich place within the canon nor the connections between all these entities, it briefly examines the Qur’ānic episode as contextualized by both canonical and folkloric

Mystik im Orient, ed. Martin Tamcke (Wiesbaden: Harrassowitz Verlag, 2010), 169.

17 Omar, "Khiḍr in the Islamic Tradition," The Muslim World 83, no. 3-4 (1993), 283, https://doi.org/10.1111/j.1478-1913.1993.tb03580.x.

18 Carl Gustav Jung, Four Archetypes (Boston, MA: Harvard University Press, 1992).

19 John Renard, Islam and the Heroic Image: Themes in Literature and the Visual Arts (Macon: Mercer University Press, 1999), 102. 
sources. It then explores a few of al-Khidir's historical functions for their trickster-like similitudes, primary of which are his role as initiator, point of contact, and sacralizer of profane spaces. Lastly, in what may appear to be an excursus, it tries to draw a conclusion about contextual necessity by reviewing the canons he operates within, examining their changing historical norms, and more critically, how anti-realist contentions eclipse the operative meaning that ultimately gives him import in the classical context.

\section{Reading al-Khiḍr as the Trickster}

The trickster is a term that begins to circulate in analysis of global folklore in the late $19^{\text {th }}$ century. The figure typically imparts some moral lesson by upsetting conventions and norms. ${ }^{20}$ He can teach his lessons through terror, but he can also beguile. Since he is deictic and syncretic, he is assigned meaning within folkloric contexts, often polytheistic. Thus, at the onset, it is easy to dismiss al-Khidir as fitting the mold because of his avowal, "I did not do this upon my own command" (Q 18:82), which redounds all perceived antinomianism to God alone. Therefore, in framing al-Khiḍr as a picaresque trickster hero while examining the Qur'ānic episode as a segment of literature, epistemic implications arise because the trickster does not typically redound to God, whereas in the Qur'ānic perspective all agency is ultimately granted by God's permission. But in probing beyond these minimalisms, the God of the Qur'ān is self-described by attributes like The Merciful and The Loving, yet simultaneously as The Avenger and "The great doer of whatever He wills" (Q 85:16). Therefore, a convergence point may exist where the Qur'ānic episode lends itself to literary analysis, and where folkloric accretions begin to subsume trickster-like aspects. Writing about the phenomenon of "The Qur'ān as Literature" Mustansir Mir argues that the theological and literary aspects of the Qur'ān are linked, although not integrally because of the Qur’ān's claim of inimitability (Q 2:23; 11:13). Therefore, while several classical exegetes treat the Qur'ān as literature, their orientations - being theological and legalistic - do not

20 George P. Hansen, The Trickster and the Paranormal (Philadelphia, PA: Xlibris, 2001). 
methodologically use literary continuity as a primary heuristic. ${ }^{21}$ Academics have, though, examined the book in that manner. For instance, with an emphasis on method, Rosalind Gwynne finds that the Qur'ān yields over thirty varieties of "explicit and implicit argument, elements of argument, techniques, and demonstrations." 22 Yet despite its textual intricacy, the believer commonly treats the text like a dithyramb or Gregorian chant, reciting it mellifluously as devotion to God, not as an exclusively literary text. Recitation itself becomes an experience of the heart whereby the state of a listener can also be impacted by mellifluous recitation, which at below fifteen hertz assists the beta state in morphing into the alpha state (within nine and fourteen hertz), a mode aiding relaxation and creativity. Thus, to insist that an exclusively literary approach should not consider these aforementioned functional dimensions of the Qur'ān, and to focus solely on figures of speech, satire, irony, and the employment of narrative techniques cannot close the convergence gap in studying characters that admittedly "appear as embodiments of abstract traits." ${ }^{23}$ Mir furthermore concedes that the text provides "sparse personal detail" about such figures. ${ }^{24}$ Therefore, although the Qur'ān simply cannot be reduced to literature, the link he moderates remains integral to analysis.

Context for the Khidr episodic narrative begins textually outside of the Qur'ān, in instructive narrations (ahāäith). The Islamic canon reports that the Quraysh sent principle adversaries of Islam, al-Nadir ibn al-Ḥārith and 'Uqbah ibn Abī Mu'ayț, to some Jewish scholars of Medina during the late Meccan period in order to inquire about Muhammad's claims to prophethood; upon receiving the delegates the Jewish religious scholars advised them to ask the Prophet of three matters: (1) the inhabitants of the cave, linked to the Sleepers of Ephesus; (2) the man who had journeyed to the extents of the east and west, linked (by some) to Alexander the Great; (3) and the Spirit (al-rū $h)$. If unable to answer, by virtue they would deem him a false

21 Mustansir Mir, "The Qur'an as Literature," Religion E Literature 20, no. 1 (1988), 51.

22 Rosalind Ward Gwynne, Logic, Rhetoric and Legal Reasoning in the Qur'àn: God's Arguments (London: RoutledgeCurzon, 2004), ix-x.

23 Ibid., 62.

24 Ibid., 52. 
prophet. When they questioned the Prophet, he promised an answer the next day, but after fifteen days the revelation had not come, and when it finally did the verses ( $Q$ 18:23-24) rebuked the Prophet for making a promise without acknowledging that all matters depend on God's will. However, in response to the three questions, the Qur'ann offers three narratives in the sürah all unified by a theme of travel: the companions of the cave flee their home, Dhū 1-Qarnayn (possessor of two horns/Alexander) travels from east to west in order to establish his dominion, and Moses travels to seek an illuminating guide. Further context is provided in a separate narration wherein a congregant asks Moses who the most knowledgeable person in the world is. When Moses ascribes that very rank to himself, God admonishes him for not ascribing all knowledge unto Him alone. ${ }^{25}$ God then subsequently alerts Moses to where he may find a "servant" in possession of greater knowledge than he. ${ }^{26}$

It is in this context that the Qur'ānic episode begins at 18:60 with Moses declaring he shall continue until he reaches the junction of the two seas. The junction can denote the temporal state between death and judgment (barzakh), whereas geographically it may relate to the meeting between the Tigris and the Euphrates around the biblical Ur, signifying the retracing of steps to where revelation began, and perhaps to where it also began to go lost. In many commentaries the in between state or junction is interpreted allegorically to indicate where saltwater and freshwater meet, where knowledge of the exoteric and the esoteric amalgamate, and to where morality perhaps conforms to a different type of understanding that can reconcile paradox. The journey necessitates a travel episode and a border crossing, and this is where Moses can find his teacher. Similarly, contemporary folklorists envisage trickster as a border-crossing archetype. Lewis Hyde compiles both generally accepted descriptive and idyllic features, arguing that "outside such traditional contexts there are no modern tricksters because trickster only comes to life in the complex terrain of polytheism" since "if the spiritual world is dominated by a single high god opposed by a single embodiment of

\footnotetext{
25 Muslim, "al-Faḍā̄il," 170.

26 Nasr et al., The Study Quran, 728-729.
} 
evil, then the ancient trickster disappears." ${ }^{27}$ Although acknowledging this Manichean oversimplification, he later makes a germinal concession that situates a place where "the practice of art and this myth collide." 28

Trickster belongs to polytheism or, lacking that, he needs at least a relationship to other powers, to people and institutions and traditions that can manage the odd double attitude of both insisting that their boundaries be respected and recognizing that in the long run their liveliness depends on having those boundaries regularly disturbed. ${ }^{29}$

The servant makes the first personal acknowledgment of error in the episode; he is widely considered to be Joshua (Yūsha' ibn Nūn) by commentators such as al-Ṭabarī (d. 310/923), al-Qurțubī (d. 671/1273), and al-Rāzì. The symbolic significance of being the son of Nūn, which can mean "fish," representing secular knowledge (or perhaps revelation), is the subject of much commentary. Episodic themes revolve around intermediate realms between life and death, exoteric adherence to the law versus esoteric knowledge, and scripture versus reason. Moses actively pursues such mysterious knowledge at a boundary crossing. Moses and Joshua then continue until realizing they have lost their "fish" (61-64). Classical commentaries like al-Zamakhsharī's direct the focus to the symbolism of discipleship and spiritual mastery; Moses directs his servant to literally retrace their steps back to the meeting place, eventually becoming the disciple to al-Khiḍr, the non-literalist. ${ }^{30}$ In classical commentaries, freshwater represents rivers with their linear and directional nature, which are constitutive of rational thought in the most basic allegorical meaning. In contrast, a saltwater sea, with its unpredictable currents and vastness, symbolizes inner allencompassing knowledge. Since neither servant nor master could recognize this intersection, they forgot their fish, which came back to life at that location. Therefore, al-Khiḍr may symbolize life that transcends the effects of time that a lens fixated on law and temporality cannot immediately grasp. In that tradition tends to

\footnotetext{
27 Lewis Hyde, Trickster Makes this World: Mischief, Myth, and Art (New York: Farrar, Straus and Giroux, 2010), 28.

28 Ibid., 38.

29 Ibid., 35-36.

30 Nasr et al., The Study Quran, 749-750.
} 
ossify, revival is often jolting, and there may be a correspondence in Atwood's review of Hyde in which she affirms that a function of tricksters is often to be "those who come along when a tradition has become too set in its ways, too orderly, too Apollonian, and shake it out of its rut." ${ }^{31}$ To the specificity of that meeting place, al-Qurtubì and other commentators mention that the place where the fish comes back to life is the spring of life, whereas if read as a symbolic narrative, Moses retracing his steps can represent the journey of the soul back to God and to primordial nature after the human fall. ${ }^{32}$ The episode continues (Q 67-71) and Moses agrees not to question the methods of the instructor: "If thou wouldst follow me, then question me not about anything, till I make mention of it to thee." (71)

Al-Rāzī points out that Moses's humility is representative of how students - even prophets - should display deference towards their teachers. From this al-Qushayrī (d. 465/1072) opines for permitting teachers to determine the parameters of journeys towards knowledge and enlightenment. ${ }^{33}$ Ibn Kathīr (d. 774/1373) mentions that Moses is initially appalled at how they board the ship without charge due to the owner recognizing al-Khider (70-74), who then quickly shifts into sabotaging the ship, nearly sinking it. If the ship is representative of the body that carries the soul through material existence, it may perhaps need to be broken by certain ascetic spiritual exercises. ${ }^{34}$ Lewis Hyde's description of the function of trickster provides more parallels:

It is at well-guarded barriers that these figures are especially tricksters, for here they must be masters of deceit if they are to proceed ... We constantly distinguish - right and wrong, sacred and profane, clean and dirty, male and female, young and old, living and dead - and in every case trickster will cross the line and confuse the distinction ... Where someone's sense of honorable behavior has left him unable to act, trickster will appear to suggest an amoral action, something right/wrong that will get life going again. Trickster is a mythic body of

31 Margaret Atwood, review of Trickster Makes This World, by Lewis Hyde, Los Angeles Times (1998), 3.

32 Nasr et al., The Study Quran, 752.

33 Ibid., 752-3.

34 Ibid., 753. 
ambiguity and ambivalence, doubleness and duplicity, contradiction and paradox. ${ }^{35}$

Of prime importance in allegorical interpretation is the tripartite division of the self, found with Ancient Greeks like Plato and in the Islamic literature which inherited the Peripatetic school. ${ }^{36}$ The tripartite division stands between the inciting self (al-nafs alammārab), the self-accusing self (al-nafs al-lawwāmab), and the self at peace (al-nafs al-mutma'innah). If the spiritual goal of mysticism is to subdue the lower two base forms of the self, al-Khidr's actions can be reunited with an understanding that reason can grasp. Winifred Morgan adds that tricksters can similarly "astonish with their ability to achieve creative breakthroughs" by embodying a "shadow side" of human nature and engaging in taboo behavior. ${ }^{37}$ Al-Khiḍr, thus, offers interpretations of his behaviors before departing. Poking a hole in the ship, while undesirable, was the better of two temporal options. However, more attention is often paid to his alarming killing of the boy. Some commentary claims the boy has murdered and escaped prosecution; other commentary says he was on that path and mercifully taken out before the age of culpability, whereas mystical readings take slaying to connote annihilating the part of one's soul that inclines towards evil, anger, and passion. Similarly, temporary restoration of the wall would dissuade the town's selfish inhabitants from discovering the treasure themselves. Representational of classical commentary, Ibn Kathīr claims that although the treasure appears to be material, it is truly some form of knowledge. The repaired wall thus represents a soul at peace, which can only be retrieved once the other two components of the self are subdued. ${ }^{38}$

While there are conceivable crossover attributes, al-Khiḍr does not fit the typical picaresque trickster hero mold. He does not, for instance, display the lewdness, lust or hyperactive sexuality found in

35 Hyde, Trickster Makes This World: Mischief, Myth and Art (New York: Farrar Straus \& Giroux, 1988), 23-24.

36 Asghar Ali Engineer, "Iqbal's 'Reconstruction of Religious Thought in Islam': A Critical Appraisal," Social Scientist 8, no. 8 (1980), 52-63, https://doi.org/10.2307/3516692.

37 Winifred Morgan, The Trickster Figure in American Literature (New York, NY: Palgrave MacMillan, 2013), 5-6, https://doi.org/10.1057/9781137344724.

38 Ibid., 754-756. 
many tricksters, although he shares traits with other boundary crossers. He crosses between worlds, often connected with water and boundaries of morality. For example, Eshu the Afro-Caribbean trickster guards the "many doors and roads which make up the human journey through life" and is able to straddle them. ${ }^{39}$ Likewise the Orcadian selkie (seal) stories of the Orkney archipelago narrate tales of seals that are able to seduce humans and go back and forth between land and sea. The selkie stories relate that such transformations happen every "seventh stream" or "ninth night" sustaining the folkloric acceptance that a mortal woman seeking selkie-man companionship must shed seven tears into sea at high tide. ${ }^{40}$ Such symbolism in numbers and repetitions of actions is common whereby a certain number of repetitions reveal a previously inexplicable meaning. Another example is the Winnebago trickster figure, Coyote, whose behavior follows such patterns. Actions are typically repeated four times, like in the tales of Hare, which are either in configurations of three or four. Al-Khidr similarly repeats his actions three times before revealing their meaning. However, in the literature there is not always an evident higher telos at play, and sometimes the import seems petty. An instance of this is Jack's motive in The Jack Tales of the Appalachian Mountains who tricks his adversaries into allowing him to drown them in the river thereby leaving him the bequeathing owner of "a farm and a house and all them sheep, and nobody to bother him." ${ }^{41}$

With these comparisons, however, we reach a limit that hinges on authorial intentionality. Enumerating particular similarities between Br'er Rabbit, Jack, and the Winnebago trickster, Lewis Hyde argues that the trickster is not the devil, and that he is amoral, not immoral. ${ }^{42}$ Nevertheless, the implications for what it would mean for comparative analysis if Hyde had come down on the other side are not clear because appropriations all change situational contexts. For

39 Susanne Iles, "Eshu, An Afro-Caribbean Divine Trickster," Sacred Hoop 29 (2000), 1.

40 "Orkneyjar: The Heritage of the Orkney Islands," orkneyjar.com/folklore /selkiefolk/sulesk.htm, accessed February 11, 2019.

41 Richard Chase, The Jack Tales, 17 ${ }^{\text {th }}$ ed. (Boston, MA: Houghton Mifflin, 1943), 174.

42 Hyde, Trickster Makes this World, 22. 
instance, by the $15^{\text {th }}$ century, when al-Suyutṭi examines Gilgamesh as Manicheans in the Middle East had appropriated him, he links him to a regional demon, serving as another example of how wide-ranging interpretations can become over time. ${ }^{43}$ Trickster narratives generally end in a mea culpa, summation of behavior, or explanation of actions in order to reconcile the contradictions between behavior and morality. The Winnebago Hare cycle narrates, "Hare was sent by Earthmaker to teach the people on earth a better life." ${ }^{44}$ Similarly, it is only after Moses fails to remain silent three times that al-Khidr explains to him the wisdom behind the outward appearance of his actions. Al-Khiḍr upsets the legal boundaries that have been set up in Moses's worldview, which is supposed to be one imbued by none other than God. But it is the same God who sends Moses a servant to disrupt that very worldview. Like Hermes and Apollo in the classical myth, Hermes steals the cattle in order to teach the audience a lesson on virtues, including regret and forgiveness, as both characters are enhanced in understanding, friendship, and newly attained musical instruments by the didactic episode. ${ }^{45}$ In a similar tenor, the relationship between al-Khidr and Moses is necessary for the story to become didactic because Moses does not gain an understanding outside of the legal sphere without first seeing the law's subversion, and the evident tricks ultimately teach him to reconcile apparent contradictions.

\section{Historical Functions of al-Khị̂r in Canonical and Folkloric Contexts}

Before an examination of the figure's historical functions, a brief conversation about classical context can serve to underscore the extent of the canon's "omni" characteristics. In encountering the Peripatetic schools of Egypt, the Levant, and Persia, the Muslim world's canon similarly adopts Hellenistic rigor and a systematic method of inquiry, including the Aristotelian virtues. In this sense,

43 Andrew R. George, The Babylonian Gilgamesh Epic: Introduction, Critical Edition and Cuneiform Texts, Volume 1 (Oxford: Oxford University Press, 2003), 88.

44 Paul Radin, Karl Kerényi, and Carl Gustav Jung, The Trickster: A Study in American Indian Mythology (New York: Schocken Books, 1988), 91.

45 Hyde, Trickster Makes this World. 
more appropriate than juxtaposing "Islam" and "the West" as canonical objects of comparison, an insurmountable task, is to view them within a binding and overarching framework of loose amalgamation and certain continuity. Nevertheless, in relation to identifying a few distinctive features of normativity, a few things can be acknowledged. Distinctive to Islam, the process of interpretation and hermeneutic consensus leads to a codification, rather than a canonization, as no ecumenical councils are convened to establish religious orthodoxy. Peter Adamson argues for a canonical semantic distinction of "philosophy in the Islamic world" because terminologically "Islamic philosophy" excludes the many non-Muslim writers, and "Arabic philosophy" discounts the indispensable writings in Persian and other languages. ${ }^{46}$ Nevertheless, a foundational book coalesces an Arabic culture of orality with existing literary civilizations, and an envelopment of canonical knowledge takes place. It adopts sophia as a speculative science used to seek answers to the most fundamental questions, including those of existence, essence, and the immaterial. This science of metaphysics precedes method concerning all questions about being qua being: first principles, causation, and the contents of the human mind and its presuppositions. In the employ of a prima scriptura theology that recognizes the fallibility of the human mind, metaphysics is studied only after mastering the qualitative (trivium) and quantitative (quadrivium) liberal arts that aid in liberating the mind from the fetters of faulty thinking by creating a balance between faith and reason ( $a l$-naql and $a l^{-}(a q l)$. In this realist view, objective reality - as synthesis of mind and matter - can be known, the mind and body are synthesized, and all mysteries remain operative whether or not they ultimately obtain. ${ }^{47}$ In this key departure Iblis (Satan) is the original nominalist as he is unwilling to conceptualize the essence of the human, and he mistakenly deems himself superior on purely arbitrary and materialistic terms.

The early internal debate on the role of reason, whether Islam is a religion of the mind or the heart, reaches a modus vivendi that

46 Peter Adamson, A History of Philosophy without Any Gaps, volume 3: Philosophy in the Islamic World (Oxford: Oxford University Press, 2018).

47 Hamza Yusuf, "Is the Matter of Metaphysics Material? Yes and No," Renovatio: The Journal of Zaytuna College 3, no. 2 (2017), 81-91. 
culminates into scholastic, normative Islam entailing several dimensions. Similar pursuits of probing all of God's possible intents as an author lead to exhausting the possibilities of linguistic meaning. Thus, when al-Farāhīīi (d. 175/791) of Oman compiles the first Arabic dictionary and develops the science of prosody in the $8^{\text {th }}$ century, the implicit driver is to minimize the philological stems of epistemic uncertainty. In the representative scholastic schools of 'Umar al-Nasafī (d. 537/1142) and al-Taftāzānī (d. 792/1390), "normative" means a rational-based formal theology (kalām), underpinned by logic and sustained by an emphasis on reason (al${ }^{c} a q l$ ) and legal theory (al-fiqh).$^{48}$ Without the formation of a synod or magisterium, the emphasis on a rationalist theology emerges organically from treating God's uncreated speech (al-nutq - trilateral root $n-t-q)$ as the grounds for formal logic (al-mantiq). Words are interpreted as signs, vibrations and attributes imbued with a reality from God, "And he taught Adam the names, all of them" (Q 2:31), and they are to be interpreted through human reason, as humans are considered rational animals. ${ }^{49}$ Additionally, exhaustive study of the Qur'ān gives birth to an inward-based spiritual practice of beautification (iḥsān), later dubbed Sufism (tașawwuf). A spiritual science not extraneous to Islam, it is challenging to succinctly define and translate nonetheless because as a science with a mystical component it may be seen through a variety of lenses. ${ }^{50}$ William Chittick categorizes the concept as an historical object and notes that its recent academic classification by Orientalists is due to their desire for "a term that would refer to various sides of Islamic civilization they found attractive and congenial and that would avoid the negative stereotypes associated with the religion of Islam stereotypes that they themselves had often propagated." ${ }^{51}$ Nevertheless, interpretations influenced by Sufism are normative and generally place a heavier emphasis on allegory. It is, ultimately, the interiorization of faith and the recognition of an essential reality that develops into an all-embracing attempt at the restoration of beauty in the human world, which when externalized can creatively manifest in various ways, from creating a mosaic, a hymn, or an architectural

\footnotetext{
48 Eric Ormsby, Ghazali: The Revival of Islam (Oxford: Oneworld, 2008).

49 Ibid., 22.

50 Omar, "Reflecting Divine Light," 167, 173.

51 William Chittick, Sufism: A Beginner's Guide (Oxford: Oneworld, 2000), 4.
} 
design. The emphasis on this inner dimension of the religion remains central up until the political and ideological contestations ushered in by the modern era, exacerbated by the effects of colonialism and globalization. ${ }^{52}$ Thus, "religious" thought is not left unaffected by the forces of secularization and quantification, and several $20^{\text {th }}$ century voices seek to deny al-Khidir of tradition in preference to reclassifying him as a chimera assigned to the realm of superstition. For instance, drivers of the politicization of Islam in the $20^{\text {th }}$ century such as Sayyid Quțb (d. 1966) reject all traditions related to al-Khiḍr; similarly, Abū 1A lá al-Mawdūdī (d. 1979) reclassifies al-Khiḍr in order to eliminate what he views as hermeneutic problems related to his lawlessness and eternal life. ${ }^{53}$

Returning now to the specific functions of al-Khidir, we will see how these functions both coalesce with and challenge classical understandings, some of which bolster the reading as a trickster. Firstly, he has historically abided as an elusive figure of immortality and conveyer of intimate esoteric understanding, functioning also as a symbol of Muslim contact and conversion, often from Christianity, in the reformulation of medieval Islamic frontier zones wherein diverse populations mixed. Al-Khidir's characteristics of being able to traverse vast distances in a short time amplified the number of claims made about his visitation to numerous worship sites. He would be rumored to attend the five daily prayers at various services across the world, a claim that survives by those open to the possibilities of what shape and what form he takes. Thus, inscriptions dedicating sites to him or claiming his visitation would historically mark numerous mosques, tombs, dervish lodges, khirqahs and zäwiyahs. These inscriptions, found first in Iraq, and later in the Arabian Peninsula, Egypt, and the Levant, served to coalesce traumatic events such as the Crusader conquests and wars with Byzantium. New patrons of architecture became increasingly keen on inscribing al-Khiḍr on monuments because it was a way of highlighting local sanctity and

52 Abdal Hakim Murad, "Rethinking Islamic Education," lecture delivered February 6, 2016 at the International Islamic University, Kuala Lumpur, Malaysia. https://www.youtube.com/watch?v=bI8y3Q_FpD4, accessed December 10, 2019.

53 Patrick Franke, Begegnung mit Khidr: Quellenstudien zum Imaginären im traditionellen Islam (Stuttgart: Franz Steiner Verlag, 2000), 369. 
respecting pre-Islamic traditions while simultaneously drawing a direct link to the new Islamic order and its related shrines. ${ }^{54}$ An apt anecdote is related by the well-known $12^{\text {th }}$ century grammarian Ibn 'Asākir (d. 571/1176) about the history of the Umayyad Mosque in Damascus, which was built upon a site that was initially a pagan sanctuary that housed a temple to Jupiter. After the Christian conquest, the site became The Cathedral of St. John. It is said that Umayyad Caliph al-Walìd had an epiphany after keeping vigil one night where he found al-Khiḍr praying near the Green Corner, which inspired him to preserve in its place the most sacred relic - John the Baptist's head - and to additionally construct an area dedicated to alKhidir in the new mosque. Maintaining a mosque that encompassed two sites that Christians venerated underscored the link between the two faiths, and according to Ethel Wolper, "emphasized a discourse of conversion and continuity." ${ }^{55}$ Thus, he became a way to fuse the old with the new in a civil manner, which coalesces with Hyde's statement that "in spite of all their disruptive behavior, tricksters are regularly honored as the creators of culture." ${ }^{56}$

Another one of the figure's common historical functions is transforming profane spaces into the sacred. This can relate to both physical space and the sacralization of being inside the heart whereby someone receives the light of the divine and journeys from inner darkness of ignorance to a station of gnosis. Commentators of this phenomenon often reference 24:35 of the Qur'ān:

God is the Light of the heavens and the earth. The parable of His Light is a niche, wherein is a lamp. The lamp is in a glass. The glass is as a shining star kindled from a blessed olive tree, neither of the East nor of the West. Its oil would well-nigh shine forth, even if no fire had touched it. Light upon light. God guides unto his Light whomsoever

54 Ethel Sara Wolper, "Khiḍr and the Politics of Place: Creating Landscapes of Continuity," in Muslims \& Others in Sacred Space, ed. Margaret Cormack (Oxford: Oxford University Press, 2013), 159, https://doi.org/10.1093/acprof:oso /9780199925049.003.0006.

55 Wolper, "Khiḍr and the Changing Frontiers of the Medieval World," Medieval Encounters 17, no. 1-2 (2011): 120-146, https://doi.org/10.1163/9789004221031 -005.

56 Hyde, The Gift, 25-26. 
He will, and God sets forth parables for mankind, and God is Knower of all things. ${ }^{57}$

For Ibn al-'Arabī (d. 638/1240) this light is synonymous with knowledge of God and the unity of existence and in explaining this he relays a personal anecdote of him seeing such a light while experiencing the loss of all sense of direction and spatial positioning. Many other mystics report this as an attainable station for a seeker. AlGhazālī (d. 505/1111) similarly speaks of the veils of light and their separation of divine reality and the world of matter. ${ }^{58}$ In this context, the function of the Khidr symbol has been to help seekers attain the station of light through spiritual transformation. Patrick Franke examines 173 stories of claimed encounters with al-Khidr from the $9^{\text {th }}$ to $12^{\text {th }}$ centuries and describes one of al-Khidrr's functions as narrator of God's endorsement of holy spaces, places, and rulers. ${ }^{59}$ Al-Khiḍr also functions as an initiate to the sacred, a guide on the path of the seeker (sālik), and al-Khidir sightings are the closest approximation to a theophany in the traditional Islamic worldview that one can document. The holy, or the experiential manifestation of sacred and numinous experience, is an approximation of the participatory aspect of sacred reality. ${ }^{60}$ It is a spiritual aspect within canonical boundaries that mainstream Muslim schools have historically tolerated. There are many reports of Sufis claiming to have met al-Khidir, either in dreams or visions. Ibn al-'Arabī, for instance, claims to have met him on three separate occasions. Irfan Omar views al-Khiḍr as a figure who functions as God's mercy in concert with the "light" of spiritual illumination and enables multitudes of the mystically inclined to gain spiritual statuses within their respective contexts, indiscriminately helping all, and not just the spiritual elite. ${ }^{61}$ A common trope in Sufi love ('ishq) poetry is when al-Khidr shows up in initiatory aspects of the spiritual quests of poets. For instance, Rūzbihān al-Baqlī of Shīrāz (d. 606/1209) claims an encounter signifying his entrance into a spiritual path towards sainthood. Al-Baqli narrates that he was at that

\footnotetext{
57 Nasr et al., The Study Quran, 878-880.

58 Omar, "Reflecting Divine Light," 175-176.

59 Franke, Begegnung mit Khidr, 1.

60 Mircea Eliade, The Sacred and the Profane: The Nature of Religion, trans. Willard R. Trask (New York, NY: Harcourt, 1959), 12.

61 Omar, "Reflecting Divine Light," 178.
} 
time, "ignorant of the sciences and realities" and that al-Khiḍr told him to eat of an apple, "all of it" which he complies with in a scene in covenant with the Biblical Eden motif. ${ }^{62}$

However, in addition to his special multimodal status within normative Islamic Sufism, he also functions as the lemma of nonnormative folkloric and new-age appropriations of Sufism. These borders are critical as the figure is often the inspiration behind architecture in the Muslim worlds where legends of chance meetings with al-Khidir abound, as do historical claims of his visitations at holy sites. The Khidr of folklore has a wide range, from helper of the wayfarer, to sometimes agent of subversion in moral systems. The expressions of al-Khiḍr made in folkloric contexts are not representative of Islamic practice per se, although there is sometimes an ambiguous overlap that is difficult to delineate; for this purpose Marshall Hodgson has dubbed phenomena of the fantastic that is neither devotional in nature nor couched in confessional terms Islamicate; the term refers to "the social and cultural complex historically associated with Islam and the Muslims, both among Muslims themselves and even when found among non-Muslims." ${ }^{63}$ In new-age spirituality's appropriation of al-Khider, it is still common to find him incorporated into cosmology as a patron saint of travelers. ${ }^{64}$ A modern example of such appropriation is Idrīs Shāh's novel The Way of the Sufi wherein al-Khidir saves two drowning people by shape shifting into a log made in order to save them; with it they meander back to the shore safely as an onlooker witnesses this miraculous deed, and it is to the questioning of the onlooker that alKhidir retorts that he assists people who have a future deed or service to fulfill. ${ }^{65}$ Similarly, in al-Ṭayyib Șāliḥ's classic Arabic novel The Wedding of Zein, a story about an unattractive yet popular Sudanese man named Zein who falls in love, al-Khiḍr's impact on society is

62 Carl W. Ernst, Rüzbihān Baqlī: Mysticism and the Rhetoric of Sainthood in Persian Sufism (Richmond, Surrey: Curzon Press, 1996), 52-53.

63 Marshall G. S. Hodgson, The Venture of Islam: Conscience and History in a World Civilization, Vol. 1: The Classical Age of Islam (Chicago: The University of Chicago Press, 1974), 59, https://doi.org/10.7208/chicago/9780226346861.001.0001.

64 Frederick William Hasluck, Christianity and Islam under the Sultans, ed. Margaret M. Hasluck (Oxford: The Clarendon Press, 1929).

65 Idries Shah, The Way of the Sufi (New York: Dutton, 1969), 161. 
quite overt and his interaction with Moses is interpreted as a metaparable about the act of interpretation. It proposes a re-reading of events surrounding Zein and his unexpected romance with Ni'mah that forces the reevaluation of love in society. ${ }^{66}$ These Islamicate functional appropriations do not fall under the rubric of the classical or the canonical, and their discursive contexts seem to adapt to societal needs in a manner consistent with a Durkheimian sociological view of religion. Nevertheless, we see that they do not preclude the possibility of either reading.

\section{Can We Interpret al-Khị̣r When a Canon Loses Its Import?}

Like the Islamic canon, the Western canon has gone through a transition inexplicably tied to its civilization being bound to empire. But the West's more recent imperial history of colonialism and the subsequent postmodern reassignment of meaning is something quite distinct and although the reassignment and eclipse of meaning in the Islamic canon occur in ways not entirely dissimilar, the West is in uncharted territory. This final section takes a step back from the close lens of examination to perhaps identify a blind spot of contemporary critical and close analysis. Manifestly, we can affirm that there is something essential and intriguing about the Green Man in that he personifies the inability to pin down meaning, and who - once defined - continues to slip free of the tethers of allegory, bucking simple interpretation where $\mathrm{x}$ stands in for $\mathrm{y}$, eschewing the fixed reductive meaning for the more complicated one. But because this interpretive overlap straddles disparate canons and is claimed by so many different traditions, as an object of comparison (tertium comparationis) constituting attributes of distinction, placing a boundary around him is also problematic. The figure by its essence eschews measurable answers and interpretations and necessitates canonical contextualization.

The changing Western rubric for meaning is pertinent here because detached from transcendence and hinged on quality the quiddity of what exactly makes something authoritative, or definitively beautiful, becomes up for debate as aesthetic tastes differ.

66 Tayeb Salih, The Wedding of Zein, and Other Stories (London: Heinemann Educational Books, 1969). 
However, differences that emerge over the necessity of a shared schema become quite pronounced and culminate into the canon wars, essentially precipitating the end of the Western canon. In literature, theories recognizing the limited field of vision appear, such as the inductive criticism of Richard Green Moulton - author of The Literary Study of the Bible - that embraces progress and simultaneously searches for universal truths. In debates on canonicity, simply making distinctions or boundaries becomes a subject of controversy. Moulton, for instance, criticizes lists of great books. This pushback makes it difficult to posit a traditional definition. Take beauty, for instance, eminently defined by Edmund Burke as "some quality in bodies acting mechanically upon the human mind by the intervention of the senses." ${ }^{17}$ This realism transforms, however, and $20^{\text {th }}$ century conservatism and traditionalism are appropriated by the likes of Russell Kirk and antirelativists. Admitting that culture is one of the three hardest words to define in English because of the hostility it garners, Raymond Williams defines high culture as that which encompasses all cultural productions of aesthetic value societally esteemed as art, and is that which is in contrast to low art produced by plebeians and philistines. ${ }^{68}$ However, simply positing such a definition with its tacit reliance upon binary opposites becomes something subject to scrutiny for alleged elitism. Nonetheless, patrimonial inheritance is necessary in shaping a societal paradigm for discussion, since without which a culture descends into chaotic relativism.

As it is connected to the contentious history of canonicity, the concept of religion is in need of much disaggregation. Tomoko Masuzawa contends that to even use this protean term as a rubric necessitates acknowledging that - as a category - the academy has left religion "unhistoricized" and "essentialized" in a manner tacitly retaining Eurocentric pluralist assumptions, such as the binary of the

67 Edmund Burke, The Works of Edmund Burke, vol. 1: A Vindication of Natural Society. An Essay on the Sublime and Beautiful: Political Miscellanies (London: George Bell \& Sons, 1909), 131.

68 Raymond Williams, Keywords: A Vocabulary of Culture and Society, revised ed. (New York: Oxford University Press, 1983), 92. 
sacred and the profane. ${ }^{69}$ For by opposites, things are known; however, when the canonical loses its import and deconstruction challenges its foundational binaries, the change in norms can be devastating to meaning. This is not a reference to a particular rift between modern scholars, (for instance, Foucault and Derrida), but rather a wider acknowledgement of the result of pushing back against hierarchies of traditional authority in favor of individual interpretive sovereignty. That humans learn by contrast, like the combination of a positive and negative theology (via negativa), is a traditional notion that necessitates binaries. Critical theorist Jonathan Culler likewise affirms that meaning in literature is (structurally) possible because of preexisting conventions, or that "Meaning is context bound, but context is boundless." ${ }^{\text {70 }}$ Particularly discernable in confessional Western examinations of non-Western heuristics and aesthetics, however, is that deconstruction utilized as the destabilization of meaning is primarily and distinctly a Western phenomenon. For instance, Thomas Kasulis comes to acknowledge that Zen ontological hierarchy asserts equality among creation, which requires a pursuit of truth (satori) from a non-positional and noetic attitude in order for one to imbibe haiku. ${ }^{71}$ Similarly, Eugen Herrigel observes that Zen archery has an it factor that eludes him despite his struggles to engage it for five persistent years. ${ }^{72}$ When Roland Barthes similarly ventures to Japan seeking for a universal transcendent signifier, he observes there that less meaning is imbued into signifiers by the bourgeois culture. Thereafter, naturally retained significance for him comes to conceptually yield a rejection of the claim that we can cognize the intentionality of an author. Again, we witness that at the end of a canon hierarchy loses its import. The Truth (with a capital T) is downgraded to another truth among competing truths. Amidst emerging relativism, the author thereby suffers a figurative

69 Tomoko Masuzawa, The Invention of World Religions: or, How European Universalism was Preserved in the Language of Pluralism (Chicago, Ill.: The University of Chicago Press, 2005), 1-2.

70 Jonathan Culler, Literary Theory (New York: Sterling Publishing Company, 2009), 91.

71 Thomas P. Kasulis, Zen Action/Zen Person (Honolulu: The University Press of Hawaii, 1981), 73.

72 Eugen Herrigel, Zen in the Art of Archery (New York: Pantheon Books Inc., 1993). 
death because to acknowledge the authority of the author is interpreted by some as a type of tyranny.

But if power is on the mind, and part and parcel of a heuristic, one might see it everywhere. Hence, included among the many traditional notions that have been interrogated in recent years are the conceptions of canonicity and normativity, affecting the very definition of what constitutes literature, which according to Terry Eagleton can no longer be objectively defined because a work's meaning and delineation are subject to the reception and negotiations of its audience. ${ }^{73}$ Nevertheless, a formalist assumption still shared in literary criticism - and theology - is that a discourse must contain coherence to be treated as a subject of comparison. ${ }^{74}$ The canonical figure obliges the canon to remain operative more so than the motif in literature. Yet all objects of comparison require identification, which is ultimately reliant upon interpretation; hermeneutics is thereby unavoidably interlocked with authority, the ability to exact what is and what is not inside an official boundary. The etymology of the word canon derives from Latin to denote "a (carpenter's) rule" and includes any text, music or art that shapes culture. In its general usage as a weapon with the power to destroy, is a sign. Thus, a canon is tied to authority of religious, political, and economic institutions of knowledge.

This entire departure is to establish that in order to contextualize al-Khidir as a figure something must be noted about these wider contexts and their changing norms. However, to adequately analyze what is distinctive about multifarious entities like the "Western" or "Islamic" canons is an inescapably subjective practice and perhaps obliges consultation beyond the academy, with mystics or percipients who are perhaps able to gauge figurative pulses of ethea. To be sure, although it is an abstruse task, some conspicuous assumptions and defining principles underpinning the path of credo and normativity are generally discernable. Unarguably, the Western canon is inseparable from the influence of the Bible. Then again, the Christian

73 Terry Eagleton, Literary Theory: An Introduction (Minneapolis: University of Minnesota Press, 1983), 8.

74 Volkhard Krech, "Religious Contacts in Past and Present Times: Aspects of a Research Programme," Religion 42, no. 2 (2012), 193, https://doi.org/10.1080 /0048721X.2012.642572. 
influence happens in medias res to an established Greco-Roman narrative, which arguably starts with Homer making an invocation to the Muse, although Hesiod claims that Muses can lie, which means, therefore, that aspects of the truth and reliability of Homer's sources and hence all authority - are put into question at their very root. ${ }^{75}$ Angst about the reliability of epistemological certitude is a thematic canonical reoccurrence, especially in regards to the essence of language as an ambiguous, unreliable, yet miraculous vehicle of transmission. Early church fathers affirm that people learn by signs. St. Augustine in the $5^{\text {th }}$ century, for instance, differentiates between a thing (res) and a sign (signum). Bifurcated they become conventional (signa naturalia), like smoke rising from a fire, or given by intention, like one using a fire to make smoke signals (signa data), but both usages form a sign that communicates from one mind to another and "causes us to think of something beyond the impression made." 76 This traditional espousal of language, (inherited from earlier theories and later challenged by Wittgenstein and others), deems words objects of sense-perception that name objects and sentences as combinations thereof. It posits that belief (credere), the proper subject of knowing (scire), is the reality lying behind the signs, requiring a familiarity with authorial intent and an explanation for the inscrutable relationship between the senses and the mind. ${ }^{77}$

However, if we consider all aforementioned notions and then look for one of the Green Man motif's manifestations in the Old Testament, an examination of the passages treating Melchizedek in Genesis unaided by scholastic commentary allows for conceptual ambiguity regarding his nature. Psalms (110) says, "You are a priest forever by my order Melchizedek." James Kugel deduces the implication from several related commentaries that the title "priest"

75 Barbara Graziosi, Inventing Homer: The Early Reception of Epic (Cambridge: Cambridge University Press, 2002), 251.

76 Andrew Louth, "Augustine on Language," Journal of Literature E Theology 3, no. 2 (1989), 151, https://doi.org/10.1093/litthe/3.2.151.

77 Gerard Watson, "St. Augustine's Theory of Language," The Maynooth Review 6, no. 2 (1982), 4 . 
means a type of permanence. ${ }^{78}$ Some of the abstruseness stems from interpreting his name, likely theophoric, to mean Meleki $i$-ședeq (My God [El Elyon] is Righteousness). As a compound of two elements "king" (melekh) and righteous (tsedeq) there are philological debates about whether it should be understood as a divine name or epithet (such as "the king or righteousness," or alternatively "my king"). Other questions arise regarding his origin. In Hebrews 7:3, coinciding with the archetypal nature of al-Khiḍr, Melchizedek is "Without father, without mother, without genealogy, having neither beginning of days nor end of life." Conversely, in early works of Hierax and a text associated to St. Augustine, a theory is raised that identifies him with the Holy Spirit. ${ }^{79}$ Consorting apocryphal works can widen the literary possibilities even more. For instance, in The Cave of Treasures Melchizedek assists Seth in exhuming and reburying Adam's body at Golgotha. ${ }^{80}$ Whereas in the gnostic perspective, Melchizedek lives, preaches, dies, and is resurrected, which is chronicled in the Nag Hamadi scripts that conflate him with Christ (which brings us back to one of the initial comparisons). Ultimately, his sudden textual appearance in the Bible without explanation leads to hermeneutical disagreement about why Abraham recognizes a Canaanite priest-king as a co-religionist but many have found it significant that after Abraham and 318 men recover his imprisoned nephew Lot, he pays homage to Melchizedek and then refuses to take any of the plunder for himself. Tremper Longman acknowledges that many stumped scholars have assigned Melchizedek meaning as a Christophany because of his enigmatic nature and status as the ultimate priest (surpassing even Aaron), a view bolstered by Martin Luther and often maintained within Protestantism, but Longman argues that the author of Hebrews "exploits the ambiguity of the story (Gen 14 \& Psalm 110) in order to make important theological claims about Jesus." Thus,

78 James Lewis Kugel, Traditions of the Bible: A Guide to the Bible as it was at the Start of the Common Era (Cambridge, Mass. \& London: Harvard University Press, 1998), 278.

79 Fred L. Horton, The Melchizedek Tradition: a critical examination of the sources to the fifth century A.D. and in the Epistle to the Hebrews (Cambridge: Cambridge University Press, 2005), 108.

80 E. A. Wallis Budge, The Book of the Cave of Treasures: A History of the Patriarchs and the Kings, Their Successors, from the Creation to the Crucifixion of Christ (London: The Religious Tract Society, 1927). 
despite the lack of an intra-canonical consensus, there are various established norms in aiding approaches at contextualization. ${ }^{81}$

To return to epistemological fault lines, the Baconian shift, intent on putting nature on the rack to be tortured for its secrets, sets the canon on an epistemic departure for later inheritors like Locke, Hume, and Kant. The manifold skepticism of empiricists and sola scriptura advocates extends to customs and contextualizing texts. For instance, John Milton's understanding of covenant still situates Melchizedek in the mediatorial office of priest and is a view that also affirms language by its very nature as ambiguous. Although as it is the very mechanism that God has chosen to communicate with mankind, Milton hesitates to deride the vehicle of transmission despite maintaining a justified skepticism of language and the transmission of truth through institutions. ${ }^{82}$ However, because the Hebrew language was left unpreserved without a prosodic dictionary for centuries, its sacerdotal status as the vessel of the Masoretic scripture raises doubts about the soundness of its transmission as words without diacritical marks or voweling points, raising questions about what can be definitively known about the text's authors, their states or their intentions. Furthermore, the science of translation is acknowledged as imprecise, and numerous theological interpretations of scripture and diverse exegetical opinions declare sundry misgivings about the unassailability of authoritative meaning. Nonetheless, Milton's expressed trepidation is not along the lines of linguistic prescriptivism; his chief contentions are rather against the reliance on customary practices that ossify and hinder the pursuit of truth. To Milton, such structures erected by custom are dangerous signifiers of obfuscation that become idolatrous transcendent commands. Satan of Paradise Lost is intentionally nuanced, metaphorical, and sophisticated in an attempt to prove that readers are generally fit and able to distinguish the truth from arguments. ${ }^{83}$ Great books of any

81 Tremper Longman, How to Read Genesis (Downers Grove, Ill.: IVP Academic, 2005), 172.

82 John T. Shawcross, John Milton: The Self and the World (Lexington, KY: University Press of Kentucky, 1993), 137.

83 Victoria Khan, "The Metaphorical Contract in Milton's Tenure of Kings and Magistrates," in Milton and Republicanism, ed. David Armitage, Armand Himy, 
canon contain problematic ideas and although the idea interminably wins out that readers should be granted agency, not all agree; for instance, Thomas Hobbes's weariness of paradiastole - how words in scripture can be misconstrued to invert morality - influences his conclusion that all interpretive power should be delegated to a sovereign since evaluative terms may "redescribe a given action" and lead to doubt and antinomianism. ${ }^{84}$

Al-Khidrr, the figure more specifically in question here, continuously escapes reductive meaning; thus, we must be weary of inherited civilizational epistemic blind spots and at the same time appreciate meritorious attributes of the "West" such as institutional backing for the seeking of redress fostered by vibrant civic debate and a robust legal tradition. As a defense mechanism for the tendency of freedom of speech to become freedom to offend in Western jurisprudence, a dueling culture evolves into a litigious one. The resultant freedoms provided thereby inculcate a specific research friendly environment. However, as naturalism and nominalism become part of regnant beliefs, the matter of shared essence becomes nil. This issue, despite some of the problems ameliorated by humanism, causes a greater challenge in defining the essence of humanity, no longer significant in history, and thus not a steadfast deterrent to the move towards transhumanism. While an appreciation for a legal theory informed by natural law was once a shared normativity, the arguments of legal positivists like John Austin delink morality and law. Classical theory thereafter loses its import in the West in ways incommensurate to any other cultures. In this way, a certain cosmology becomes discernible as influenced by the reeling embrace of an ideological position of scientism that reduces mysteries to matter and the framing of consciousness as a material epiphenomenon in the brain. ${ }^{85}$ There is an underpinning affirmation of progress. For despite an initial resistance to the decimal system, the West's mastery of numeracy enabling measurement of factors like

and Quentin Skinner (Cambridge: Cambridge University Press, 1995), 91, https://doi.org/10.1017/CBO9780511598456.006.

84 Quentin Skinner, "Thomas Hobbes: Rhetoric and the Construction of Morality," in Proceedings of the British Academy, volume 76: 1990 Lectures and Memoirs (Oxford \& New York: Oxford University Press, 1991), 1-61.

85 Rare exceptions to this constitute issues in quantum physics like non-locality. 
height, speed, size, and temperature hold its secret to temporal power, but these things also speak to a certain degeneracy in virtue where at times episteme and techne overtake sophia. ${ }^{86}$ Mysteries cannot all be aggregated, however. Arguably no other civilization could have produced the aerial nuclear bomb except the West, unparalleled in its precision of warfare. ${ }^{87}$ Furthermore, the sheer amount of energy allocated towards all things quantitative to the dereliction of the humanities, the death throes of which are hard to ignore, evince signs as to why modern Western culture - now global - experiences a felt flatness. Charles Taylor notes the pervasiveness of the sense that "with the eclipse of the transcendent, something may have been lost" whereby sacred rituals have been replaced by solemnizing crucial life moments with yet more and more material consumption. ${ }^{88}$ The Qur'ān (22:74) in relation to this says "They did not measure God with His true measure." Therefore, with certain admirable advances, blind spots widen in other areas and the danger of celebrating the fine-tuning of this, expeditiously advancing, quantifying lens in relation to the figure in question here who is an extension of God's light and mercy is that, like God, as a paradox he cannot be pinned down quantitatively.

\section{Conclusion}

Criticism for the propensity of dead white males to dominate the canon prods reflections on the appropriate retributive responses to a history of repressive male Anglo hegemony. On the other hand, critiques like Alan Bloom's unnervingly rail against the experimental solution of cultural relativism that props up equality at the expense of quality. ${ }^{89}$ Fredrick Douglass makes quite a strong case that, as a slave in early $19^{\text {th }}$ century America, simply accessing progymnasmata like

86 Adam Parfitt, David Price, and Marcus Weeks, A Measure of Everything: An Illustrated Guide to the Science of Measurement, ed. Christopher Joseph (Buffalo, NY: Firefly Books, 2005), 1.

87 Sven Lindqvist, A History of Bombing, trans. Linda Haverty Rugg (New York: New Press, 2003), 351.

88 Charles Taylor, A Secular Age (Cambridge, Mass. \& London: Belknap Press of Harvard University Press, 2007), 307, https://doi.org/10.2307/j.ctvxrpz54.

89 Allan Bloom, The Closing of the American Mind (New York: Simon \& Schuster, 1987). 
"The Columbian Orator" is what ultimately aids him in his literacy, oration, and prose, providing him with the tools necessary to fight and abolish slavery. As follows, the reason why Ed Hirsch and Harold Bloom compiled lists of necessarily canonical knowledge is because while it is true that all cultures are ultimately creole, or "omni" in the words of Albert Murray, to remain a neophyte in a civilization's shared schema is disempowering because to be conservative with language, that is to look back at the past with conservation, is to be powerful. The converse is cultural illiteracy and the reliance on free association, which is consequently disempowering. Furthermore, whether via the tropological vision of covenant theology or via postmodern nihilism influenced by the uncertainty principle, theories continue to elevate the reader's sovereignty in interpreting signs, while simultaneously maintaining incredulity towards the general unreliability of all observers. However, the simple acknowledgment of antinomianism is a tacit recognition of an established border; crossing an established border is a breach of sacred or social boundaries that requires redress.

To conclude, conceptual problems remain when the Green Man is removed from a canon because he shares a controversial space ranging from a revered Biblical, Buddhist or Qur’ānic figure to sharing likenesses with the folkloric trickster who embodies characteristics antinomian and perhaps satanic. And what do we do with this wide range? We have understood that divine knowledge may be received in the form of Moses's legal understanding, or as alKhiḍr's intuitive knowledge, and that these understandings are complementary, and not necessarily in competition. Therefore, the stronger the case is made for a Khidr of archetypal origins the less appropriate the motif becomes for more parochial and regional engagement confined within a comparison between Islam and JudeoChristianity or the West. The universal is in contention with a mode of engagement that is submerged in narrower Muslim polemic. Inheritors of sequential research - in the chain of Western studies of Islam and Orientalism - draw our attention to the way these two traditions are intimately linked, and how the surah of The Cave directly responds to conversations that take place in earlier sources 
like The Alexander Romance and prior religious dispensations. ${ }^{90}$ However, in folkloric and religious contexts, intentionality is what ultimately provides real import to a character. Even though there is multimodality within the canon, when norms significantly change and a canon ends, meaning is reassigned and a figure's entire significance breaks down. If we rely on the unquestioned assumptions of the age, that things which are not proven empirically or by the verification principle are meaningless, how can we probe the reality of a character that belongs to categories of theology and metaphysics that are rendered entirely insignificant? In the examination of the Qur'ānic episode, enough identifiable similarities exist to establish more than a conceptually unilateral link to other traditions. And that is enough to substantiate the inclusion of the final excursus. Furthermore, upon examination of the figure's historical functions as a point of contact and sacralizer of profane spaces, there is much to probe in making further connections. But in sharing analogous characteristics, and in some cases function and telos, one can conceptualize al-Khidr as the Green Man who is able to straddle both canonical and non-canonical discourses as well as spaces of the sacred and the profane. In doing so, he can be simultaneously identified as an interreligious and an intrareligious figure with the ability to reconcile paradoxes and moral contradictions with a different type of logic. However, what is still challenging is to conceptually reconcile his saliently calling to moral behavior while simultaneously committing disturbing trickster-like acts without being couched in a canonical context because the hierarchy of monotheism in some ways extends less literary license than the polytheistic operations of folklore. Thus, at the teleological level some of the analogous literary features break down. Buddha is framed as a compassionate trickster from a literary perspective for reasons ultimately dependent on the norms provided by normative Buddhism. Likewise, this analysis reveals that to posit features about al-Khider, (or any other canonical figure for that matter), necessarily requires consultation with the scholastic interlocutors of the figure's respective context.

90 Reynolds, The Qur'ān and the Bible: Text and Commentary (New Haven: Yale University Press, 2018). 


\section{DISCLOSURE STATEMENT}

No potential conflict of interest was reported by the author.

\section{ACKNOWLEDGMENTS}

The genesis of this paper comes out of fruitful discussions with Carol Burke on ethnography in Afghanistan and her perspectives on tricksters in folklore and film. I would like to express my gratitude to her for invaluable feedback. I would also like to express my gratitude to Jack Miles for his instructive comments on this manuscript, and larger questions of hermeneutics. Lastly, I am indebted to Hamza Yusuf Hanson for a guiding conversation on al-Khidr while seated fortuitously on the floor of al-Masjid al-Nabawi on the auspicious occasion of Rabī` al-awwal, 1440.

\section{BIBLIOGRAPHY}

Adamson, Peter. A History of Philosophy without Any Gaps, volume 3: Philosophy in the Islamic World. Oxford: Oxford University Press, 2018.

Atwood, Margaret. Review of Trickster Makes This World, by Lewis Hyde. Los Angeles Times (1998). https://www.latimes.com/archives/la-xpm-1998-jan-25-bk11790-story.html. Accessed December 10, 2019.

Bloom, Allan. The Closing of the American Mind. New York: Simon \& Schuster, 1987.

Budge, E. A. Wallis. The Book of the Cave of Treasures: A History of the Patriarchs and the Kings, Their Successors, from the Creation to the Crucifixion of Christ. London: The Religious Tract Society, 1927.

Burke, Edmund. The Works of Edmund Burke, vol. 1: A Vindication of Natural Society. An Essay on the Sublime and Beautiful: Political Miscellanies. London: George Bell \& Sons, 1909.

Chase, Richard. The Jack Tales. $17^{\text {th }}$ ed. Boston, MA: Houghton Mifflin, 1943.

Chittick, William. Sufism: A Beginner's Guide. Oxford: Oneworld, 2000.

Culler, Jonathan. Literary Theory. New York: Sterling Publishing Company, 2009.

Eagleton, Terry. Literary Theory: An Introduction. Minneapolis: University of Minnesota Press, 1983.

Eliade, Mircea. The Sacred and the Profane: The Nature of Religion. Translated by Willard R. Trask. New York, NY: Harcourt, 1959. 
Engineer, Asghar Ali. "Iqbal's 'Reconstruction of Religious Thought in Islam': A Critical Appraisal." Social Scientist 8, no. 8 (1980): 52-63. https://doi.org $/ 10.2307 / 3516692$.

Ernst, Carl W. Rüzbihān Baqlī: Mysticism and the Rhetoric of Sainthood in Persian Sufism. Richmond, Surrey: Curzon Press, 1996.

Franke, Patrick. Begegnung mit Khidr: Quellenstudien zum Imaginären im traditionellen Islam. Stuttgart: Franz Steiner Verlag, 2000.

George, Andrew R. The Babylonian Gilgamesh Epic: Introduction, Critical Edition and Cuneiform Texts, Volume 1. Oxford: Oxford University Press, 2003.

Graziosi, Barbara. Inventing Homer: The Early Reception of Epic. Cambridge: Cambridge University Press, 2002.

Gwynne, Rosalind Ward. Logic, Rhetoric and Legal Reasoning in the Qur'ān: God's Arguments. London: RoutledgeCurzon, 2004.

Hansen, George P. The Trickster and the Paranormal. Philadelphia, PA: Xlibris, 2001.

Hasluck, Frederick William. Christianity and Islam under the Sultans. Edited by Margaret M. Hasluck. Oxford: The Clarendon Pres, 1929.

Herrigel, Eugen. Zen in the Art of Archery. New York: Pantheon Books Inc., 1993.

Hodgson, Marshall G. S. The Venture of Islam: Conscience and History in a World Civilization, Vol. 1: The Classical Age of Islam. Chicago: The University of Chicago Press, 1974. https://doi.org/10.7208/chicago/9780226346861.001 .0001 .

Horton, Fred L. The Melchizedek Tradition: a critical examination of the sources to the fifth century A.D. and in the Epistle to the Hebrews. Cambridge: Cambridge University Press, 2005.

Hyde, Lewis. The Gift: Imagination and the Erotic Life of Property. New York: Random House, 1988.

- Trickster Makes this World: Mischief, Myth, and Art. New York: Farrar, Straus and Giroux, 2010.

Iles, Susanne. "Eshu, an Afro-Caribbean Divine Trickster." Sacred Hoop 29 (Summer 2000): 17 .

Jung, Carl Gustav. Four Archetypes. Boston, MA: Harvard University Press, 1992.

Kāshifī-Sabzawārī, Husayn Wāciz. The Royal Book of Spiritual Chivalry (Futūwat nāmah-yi sulțānì). Translated by Jay R. Crook. Chicago: Great Books of the Islamic World, 2000.

Kasulis, Thomas P. Zen Action/Zen Person. Honolulu: The University Press of Hawaii, 1981.

Khan, Victoria. "The Metaphorical Contract in Milton's Tenure of Kings and Magistrates." In Milton and Republicanism, edited by David Armitage, 
Armand Himy and Quentin Skinner, 82-105. Cambridge: Cambridge University Press, 1995. https://doi.org/10.1017/CBO9780511598456.006.

Krech, Volkhard. "Religious Contacts in Past and Present Times: Aspects of a Research Programme." Religion 42, no. 2 (2012): 191-213. https://doi.org /10.1080/0048721X.2012.642572.

Kugel, James Lewis. Traditions of the Bible: A Guide to the Bible as it was at the Start of the Common Era. Cambridge, Mass. \& London: Harvard University Press, 1998.

Lawrence, Bruce B. Shahrastani on the Indian Religions. The Hague: Mouton, 1976. https://doi.org/10.1515/9783110800999.

Lindqvist, Sven. A History of Bombing. Translated by Linda Haverty Rugg. New York: New Press, 2003.

Longman, Tremper. How to Read Genesis. Downers Grove, Ill.: IVP Academic, 2005.

Louth, Andrew. "Augustine on Language." Journal of Literature \& Theology 3, no. 2 (1989): 151-158. https://doi.org/10.1093/litthe/3.2.151.

Lucas, George. "Yoda Is Supposed to be just a Normal Guy." https://www.clickhole.com/yoda-is-supposed-to-be-just-a-normal-guy1829478120. Accessed October 11, 2019.

Masuzawa, Tomoko. The Invention of World Religions: or, How European Universalism was Preserved in the Language of Pluralism. Chicago, Ill.: The University of Chicago Press, 2005.

McClintock, Sara L. "Compassionate Trickster: The Buddha as a Literary Character in the Narratives of Early Indian Buddhism." Journal of the American Academy of Religion 79, no. 1 (2011): 90-112. https://doi.org/10.1093/jaarel/lfq061.

Mir, Mustansir. "The Qur'an as Literature.” Religion E Literature 20, no. 1 (1988): 4964.

Morgan, Winifred. The Trickster Figure in American Literature. New York, NY: Palgrave MacMillan, 2013. https://doi.org/10.1057/9781137344724.

Murad, Abdal Hakim. "Rethinking Islamic Education." Lecture delivered February 6, 2016 at the International Islamic University, Kuala Lumpur, Malaysia. https://www.youtube.com/watch?v=bI8y3Q_FpD4. Accessed December 10, 2019.

Muslim, Abū l-Ḥusayn Muslim ibn al-Hajjāj al-Qushayrī. Șaḥīh Muslim. 5 vols. Edited by Muḥammad Fu’ād 'Abd al-Bāqī. Cairo: Dār Iḥyā' al-Kutub al-'Arabiyyah, 1955.

Nasr, Seyyed Hossein, Caner K. Dagli, Maria Massi Dakake, Joseph E. B. Lumbard, and Mohammad Rustom, eds. The Study Quran: A New Translation and Commentary. New York, NY: HarperOne, an Imprint of HarperCollins Publishers, 2017. 
Omar, Irfan A. "Khiḍr in the Islamic Tradition." The Muslim World 83, no. 3-4 (1993): 279-294. https://doi.org/10.1111/j.1478-1913.1993.tb03580.x.

- "Reflecting Divine Light: al-Khidr as an Embodiment of God's Mercy (rabma)." In Gotteserlebnis und Gotteslehre: Christliche und islamische Mystik im Orient, edited by Martin Tamcke, 167-180. Wiesbaden: Harrassowitz Verlag, 2010.

"Orkneyjar: The Heritage of the Orkney Islands." orkneyjar.com/folklore /selkiefolk/sulesk.htm, accessed February 11, 2019.

Ormsby, Eric. Ghazali: The Revival of Islam. Oxford: Oneworld, 2008.

Parfitt, Adam, David Price, and Marcus Weeks. A Measure of Everything: An Illustrated Guide to the Science of Measurement. Edited by Christopher Joseph. Buffalo, NY: Firefly Books, 2005.

Pinkham, Mark Amaru. Guardians of the Holy Grail: The Knights Templar, John the Baptist, and the Water of Life. Kempton, IL: Adventures Unlimited Press, 2004.

Radin, Paul, Karl Kerényi, and Carl Gustav Jung. The Trickster: A Study in American Indian Mythology. New York: Schocken Books, 1988.

Renard, John. Islam and the Heroic Image: Themes in Literature and the Visual Arts. Macon: Mercer University Press, 1999.

Reynolds, Gabriel Said. The Qur'àn and the Bible: Text and Commentary. Qurān translation by Ali Quli Qarai. New Haven \& London: Yale University Press, 2018.

Salih, Tayeb. The Wedding of Zein, and Other Stories. London: Heinemann Educational Books, 1969.

Shah, Idries. The Way of the Sufi. New York: Dutton, 1969.

al-Shahrastānī, Abū l-Fatḥ Tāj al-Dīn Muḥammad ibn 'Abd al-Karīm. al-Milal wa-lnị̣al. Edited by Amīr 'Alī Mahnā and 'Alī Ḥasan Fā'ūr. $3^{\text {rd }}$ ed. Beirut: Dār alMa'rifah, 1993.

Shawcross, John T. John Milton: The Self and the World. Lexington, KY: University Press of Kentucky, 1993.

Skinner, Quentin. "Thomas Hobbes: Rhetoric and the Construction of Morality." In Proceedings of the British Academy, volume 76: 1990 Lectures and Memoirs. Oxford \& New York: Oxford University Press, 1991, 1-61.

Taylor, Charles. A Secular Age. Cambridge, Mass. \& London: Belknap Press of Harvard University Press, 2007. https://doi.org/10.2307/j.ctvxrpz54.

van Bladel, Kevin. "The Alexander Legend in the Qur'ān 18:83-102." In The Qur'ān and its Historical Context, edited by Gabriel Said Reynolds, 175-203. London \& New York: Routledge, 2008.

Watson, Gerard. "St. Augustine's Theory of Language." The Maynooth Review 6, no. 2 (1982), 4-20. 
Wensinck, Arent Jan. "al-Khadir (al-Khiḍr)." In Encyclopaedia of Islam. Third impression. Edited by P. Bearman, Th. Bianquis, C. E. Bosworth, E. van Donzel, and W. P. Heinrichs. Leiden: Brill, 1997, IV, 902-905.

Williams, Raymond. Keywords: A Vocabulary of Culture and Society. Revised ed. New York: Oxford University Press, 1983.

Wolper, Ethel Sara. "Khiḍr and the Changing Frontiers of the Medieval World," Medieval Encounters 17, no. 1-2 (2011): 120-146, https://doi.org/10.1163 /9789004221031_005.

- "Khider and the Politics of Place: Creating Landscapes of Continuity." In Muslims \& Others in Sacred Space, edited by Margaret Cormack, 147-163. Oxford: Oxford University Press, 2013. https://doi.org/10.1093/acprof:oso /9780199925049.003.0006.

Yusuf, Hamza. "Buddha in the Qurān?" In Common Ground Between Islam E Buddhism by Reza Shah Kazemi, 113-136. Louisville, KY: Fons Vitae, 2010.

- "Is the Matter of Metaphysics Material? Yes and No." Renovatio: The Journal of Zaytuna College 3, no. 2 (2017): 81-91. 